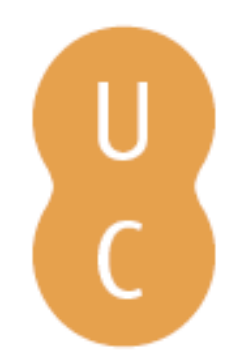

\title{
pombalina
}

\section{Blood stains analysis on clothes: a case report}

Autor(es): $\quad$ Verzeletti, A.; Cortellini, V.; Cerri, N.; Ferrari, F. De Publicado por: Imprensa da Universidade de Coimbra; International Academy of Legal

URL

persistente: URI:http://hdl.handle.net/10316.2/31725

DOI: $\quad$ DOI:http://dx.doi.org/10.14195/978-989-26-0173-1_9

Accessed : $\quad$ 26-Apr-2023 05:44:42

A navegação consulta e descarregamento dos títulos inseridos nas Bibliotecas Digitais UC Digitalis, UC Pombalina e UC Impactum, pressupõem a aceitação plena e sem reservas dos Termos e Condições de Uso destas Bibliotecas Digitais, disponíveis em https://digitalis.uc.pt/pt-pt/termos.

Conforme exposto nos referidos Termos e Condições de Uso, o descarregamento de títulos de acesso restrito requer uma licença válida de autorização devendo o utilizador aceder ao(s) documento(s) a partir de um endereço de IP da instituição detentora da supramencionada licença.

Ao utilizador é apenas permitido o descarregamento para uso pessoal, pelo que o emprego do(s) título(s) descarregado(s) para outro fim, designadamente comercial, carece de autorização do respetivo autor ou editor da obra.

Na medida em que todas as obras da UC Digitalis se encontram protegidas pelo Código do Direito de Autor e Direitos Conexos e demais legislação aplicável, toda a cópia, parcial ou total, deste documento, nos casos em que é legalmente admitida, deverá conter ou fazer-se acompanhar por este aviso.

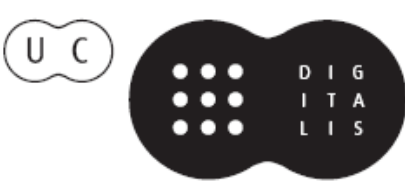




\section{Duarte Nuno Vieira Anthony Busuttil \\ Denis Cusack • Philip Beth}
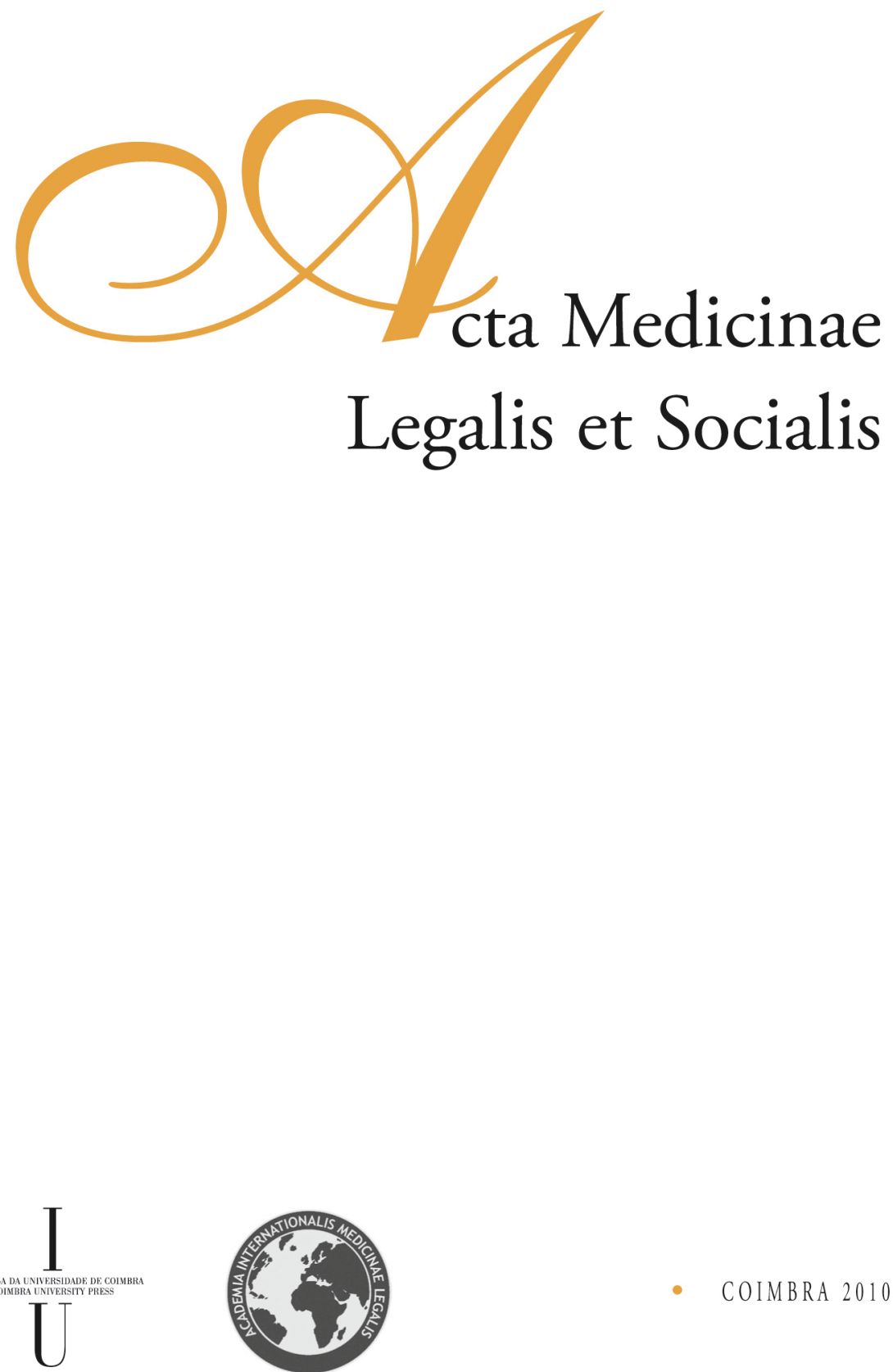


\author{
A. Verzeletti, V. Cortellini, N. Cerri, F. De Ferrari \\ Department of Forensic Medicine, University of Brescia, Brescia, Italy
}

\title{
BLOOD STAINS ANALYSIS ON CLOTHES: A CASE REPORT
}

\begin{abstract}
Some years ago a woman was found dead in her husband's factory, with multiple head injuries. The crime scene showed a lot of blood stains, different in form and dimension. The woman's husband was the first and only suspect of the murder. He was the first to reach the crime scene and a lot of blood was found on his clothes, while his shoes were clean. The suspect said he was dirty because of having trampled on the bloody floor and also because of having touched his wife's bloody body. An analysis of the blood stains on the man's clothes and their compatibility with the dynamic of the murder were requested by the judge during the trial. The possibility for the suspect of making himself dirty by embracing the dead corpse and/or by trampling the blood on the floor was investigated. The collected data were very useful for providing valuable information for the accurate reconstruction of the crime history.
\end{abstract}

\section{Introduction}

Few years ago a woman was found dead in her husband's factory. The cause of death was identified in multiple head injuries with skull fractures and neck vessel injury. The body was found lying on the floor, near a washing machine, and the crime scene showed many blood stains, different in form and dimension, on the floor, on the walls and on the washing machine.

The woman's husband was the first and only suspect of the murder. He was the first to reach the crime scene and a lot of blood was found on his clothes. In particular, a big blood stain was found on the front of his shirt and some smaller stains (round and oval drops) on its front, on its sleeves and collar. Besides, on the internal surface of the shirt, a large blood stain was also found. On the proximal side of the trousers some little drops of blood, almost all round shaped, were detected. The man's shoes were instead apparently clean, without macroscopic evidence of blood. The suspect explained he was dirty because of having trampled on the bloody floor and also because of having touched his wife's bloody body.

An analysis of the blood stains on the man's clothes and their compatibility with the dynamic of the murder were requested by the judge during the trial. As well the possibility for the suspect of making himself dirty by embracing the dead corpse and/ 
or by trampling the blood on the floor was investigated. The possibility of soiling the internal surface of the shirt was also evaluated, according to the suspect's statements.

\section{Materials and methods}

At the beginning, the stains on the clothes were submitted to the generic diagnosis, using TLC (Thin Layer Chromatography), to verify their bloody nature. On the shoes the search of secret bloody stains was performed, using "Luminol". Genomic DNA was extracted from the samples using Chelex ${ }^{\circledR} 100$ method and typed using the commercial kit AmpFlSTR ${ }^{\circledR}$ Identifiler (Applied Biosystems, Foster City, CA, USA) in a GeneAmp ${ }^{\circledR}$ PCR System 9700 Gold Plate (Applied Biosystems, Foster City, CA, USA), according to the AmpFISTR ${ }^{\circledR}$ Identifiler protocol. Alleles were separated by ABI PRISM 310 capillary electrophoresis using Gene Scan ${ }^{\text {TM}}$-LIZTM 500 (Applied Biosystems, Foster City, CA, USA) as internal standard and an allelic ladder to evaluate the sizes of the PCR products.

The electrophoresis results were analysed using the software GeneMapper ${ }^{\circledR}$ ID v3.2 (Applied Biosystems, Foster City, CA, USA).

\section{Results and discussion}

Some remarks on the production of the blood stains and their compatibility with the reconstruction of the crime were evaluated.

In particular, the bloody nature of the stains was demonstrated and a genetic female profile (victim's profile) was obtained by some blood stains typing.

On the shirt diffused blood stains were visible, some of them of moderate size, due to an absorption of bloody material on the tissue by direct contact and also by blood fallen from a short distance (Fig. 1). The right anterior portion showed a blood smear with characteristics of staining from the internal to the external surface of the tissue (Fig. 4). This element gives evidence for the hypothesis that the shirt had been stained in the same place or that the shirt, dressed entirely open and outside the trousers, had been reached on the internal surface by blood thrown in a moderate amount from a short distance, or that the shirt, not worn, had come in contact with a blood-stained surface (the victim's body or other surfaces).

On the shirt and on the trousers, bloody trails were also present (Figg. 2,3,5,6). These can be attributed to spatters (which are expression of blood from a source not in contact with the garment) of various dimensions, some of them with a pointed shape. These bloodstains can be classified mainly into medium-velocity impact spatters. The spatters can be considered as stains originating from the victim's body during the wounding, produced by the murder weapon. The different areas, the pattern and the variety of the spatters, show that they originated from different directions and in different moments. The small spatters located mainly on the left anterior side and on the right sleeve of the shirt and on the trousers also appeared to be compatible to this mechanism of production, attributing to medium-high velocity impact spatters. Another hypothesis was that such spatters originated after treading on a blood pool on 
the floor. Such a hypothesis cannot be taken in consideration because of an absence of massive stains left either by shoes (Figg. 7,8) or by the extreme part of the trousers (Fig. 5); in particular, all those spatters, previously taken in consideration, and which take us back to medium-high velocity impact, cannot be compatible with such a hypothesis, in which blood drops take an anti-gravitational route.

The collected data were very useful for providing valuable information for the accurate reconstruction of the crime history.

\section{References}

BEVEL T, GARDNER RM. Bloodstain pattern analysis: with an introduction to crime scene reconstruction. Boca Raton, FL, CRC Press, 2 ${ }^{\text {nd }}$ Edition, 2002.

BUTLER JM. Forensic DNA typing. UK, Academic Press, 2005.

FARAGO A. Detection of minute traces of blood by thin-layer chromatography. J Chromatography, 21(1):156-7, 1966.

GROSS AM, HARRIS KA, KALDUN GL. The effect of luminol on presumptive tests and DNA analysis using the polymerase chain reaction. J Forensic Sci, 44(4):837-840, 1999.

JAMES SH, KISH PE, SUTTON TP. Principles of bloodstain pattern analysis. Theory and practice. Boca Raton, FL, CRC Press, 2005.

JAMES SH, ECKERT WG. Interpretation of bloodstain evidence at crime scenes. Boca Raton, FL, CRC Press, 1999.

JAMES SH, EDEL CF. Bloodstain pattern interpretation. Introduction to forensic sciences. Boca Raton, FL, CRC Press, 1997.

MACDONELL HL. Criminalistics. Bloodstain examination. Forensic Sci, 3:37.1-37.26, 1981.

PIZZOLA PA, ROTH S, DEFOREST PR. Blood droplet dynamics-I. J Forensic Sci, 31(1): 36-49, 1986.

PIZZOLA PA, ROTH S, DEFOREST PR. Blood droplet dynamics-II. J Forensic Sci, 31(1): 50-64, 1986.

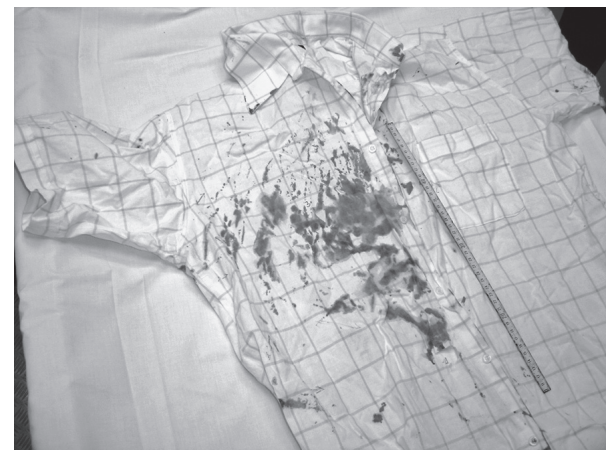

Figure 1 - External surface of the shirt. A large blood stain on its front and some little stains (round and oval drops) on its front, on its sleeves and on its collar.

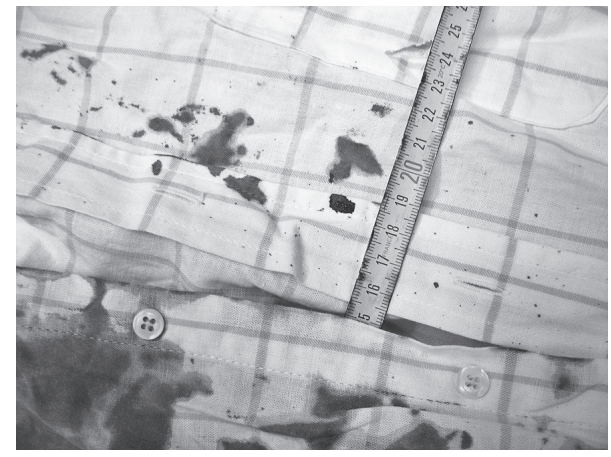

Figure 2 - External surface of the shirt.

Particular of some little blood stains and part of the large stain on its front. 


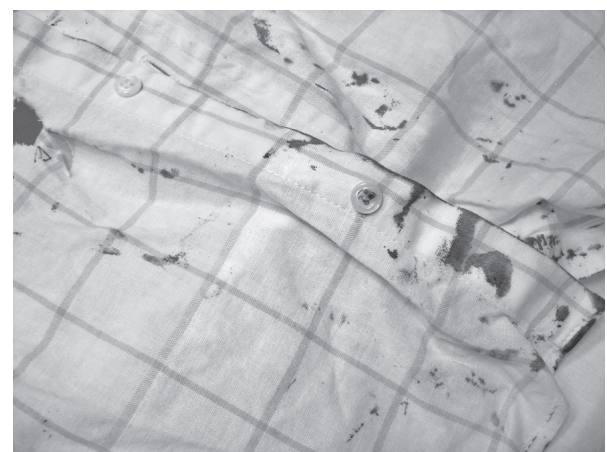

Figure 3 - External surface of the shirt. Particular of some little blood stains.

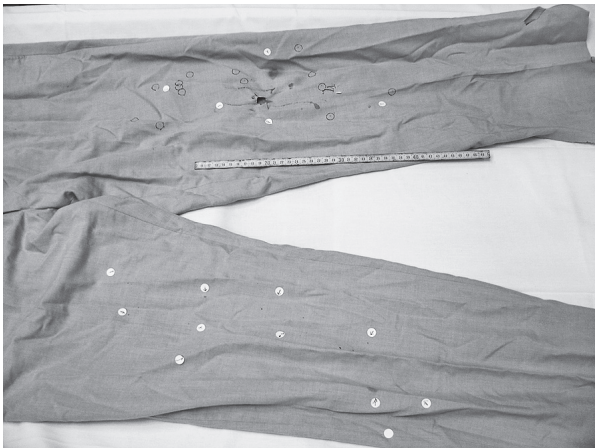

Figure 5 - Trousers. On the frontal side some little drops of blood, almost all round shaped.

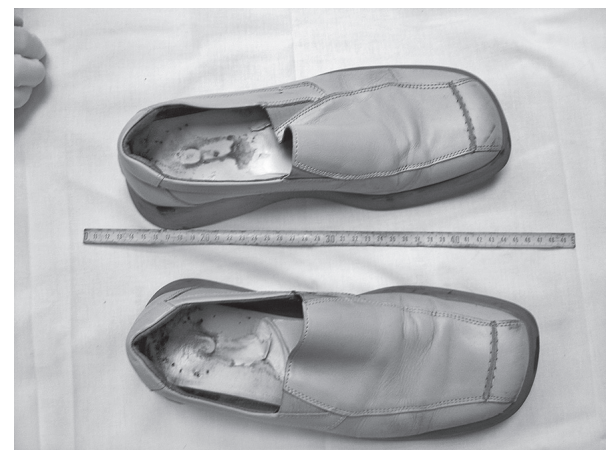

Figure 7 - Shoes. No macroscopic evidence of blood stains on the frontal side.

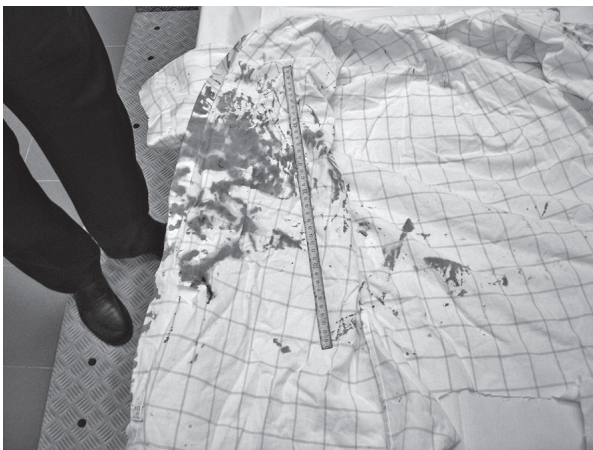

Figure 4 - Internal surface of the shirt. A large blood stain.

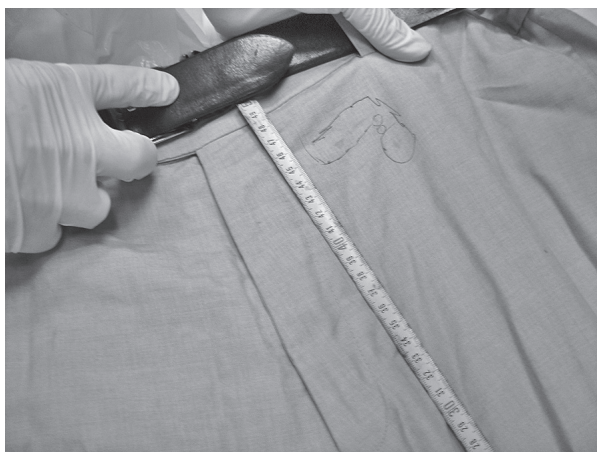

Figure 6 - Trousers. Particular of some little drops of blood, almost all round shaped, on the frontal side.

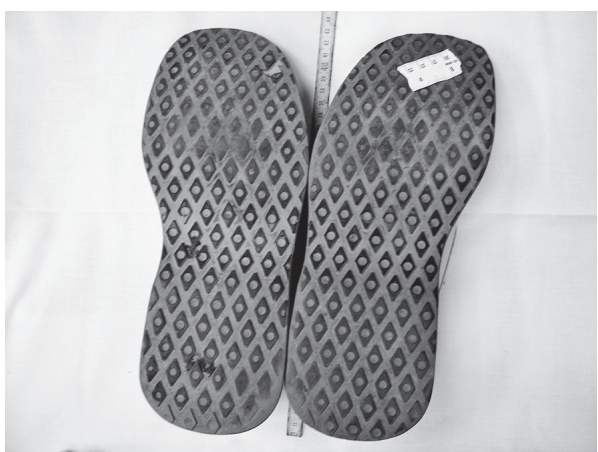

Figure 8 - Shoes. No macroscopic evidence of blood stains on the soles. 